\title{
Literary Sisters
}





\title{
Literary Sisters
}

\section{Dorothy West and Her Circle}

\author{
A BIOGRAPHY OF THE \\ HARLEM RENAISSANCE
}

Verner D. Mitchell

and Cynthia Davis

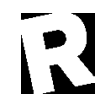

Rutgers University Press

New Brunswick, New Jersey, and London 


\section{Library of Congress Cataloging-in-Publication Data}

Mitchell, Verner D., 1957-

Literary sisters : Dorothy West and her circle, a biography of the Harlem Renaissance / Verner D. Mitchell and Cynthia Davis.

p. $\mathrm{cm}$.

Includes bibliographical references and index.

ISBN 978-0-8135-5145-6 (hardcover : alk. paper)

ISBN 978-0-8135-5146-3 (pbk. : alk. paper)

1. American literature-African American authors-History and criticism.

2. American literature-Women authors-History and criticism.

3. West, Dorothy, 1907-1998-Criticism and interpretation.

4. African American women-Intellectual life. 5. African American women in literature. 6. Harlem (New York, N.Y.) - Intellectual life-20th century.

7. African American arts-New York (State)-New York.

8. Harlem Renaissance. I. Davis, Cynthia, 1946- II. Title. PS153.N5M58 2012

813.5209896073 - dc22

2011001039

A British Cataloging-in-Publication record for this book is available from the British Library.

Copyright (C) 2012 by Verner D. Mitchell and Cynthia Davis

All rights reserved

No part of this book may be reproduced or utilized in any form or by any means, electronic or mechanical, or by any information storage and retrieval system, without written permission from the publisher. Please contact Rutgers University Press, 100 Joyce Kilmer Avenue, Piscataway, NJ 08854-8099. The only exception to this prohibition is "fair use" as defined by U.S. copyright law.

Visit our Web site: http://rutgerspress.rutgers.edu

Manufactured in the United States of America 
For Jared, Courtney, Dylan, Jack, Caroline, and Sofia 
